УДК 943.988

DOI https://doi.org/10.32849/2663-5313.2019.7.34

\title{
Сгор Назимко,
}

докт. юрид. наук, старший науковий співробітник,

професор кафедри кримінально-правових дисииплін та судових експертиз

Донецького юридичного інституту Міністерства внутрішніх справ України

Юрій Пайда,

канд. юрид. наук, доцент,

професор кафедри економіко-гуманітарних дисииплін та права

Кам'янеиь-Подільського податкового інституту

Марина Андріяшевсъка,

адвокат

\section{СТАНОВЛЕННЯ ЮВЕНАЛЬНОЇ ВІКТИМОЛОГІЇ ЯК ОКРЕМОГО КРИМІНОЛОГІЧНОГО ВЧЕННЯ}

У статті розкрито особливості становлення ювенальної віктимології як окремого кримінологічного вчення. Аналізуються історичні витоки зародження та розвитку ювенальної віктимологіі. Зазначається, що загальноісторична природність зародження ювенальної віктимології зумовлена не чим іншим, як саме давнім, значним, гостро позитивним иіннісно-етичним, моральним, тобто аксіологічним суспільним ставленням до всього комплексу соціальних, кримінально-правових та інших проблем дитинства, неповноліття, малолітства тощо. Стверджується, що ювенальна віктимологія становить досить актуальну, соціально важливу сферу науково-кримінологічного знання та дослідження. Дана система/галузь науково-кримінологічного знання зумовлюється власним, очевидним надзвичайно гострим сочіальним та суто кримінологічним причинно-предметним контекстом - вчиненням кримінальних злочинів проти неповнолітніх та/або малолітніх осіб, причинами та наслідками вчинення проти них тих чи інших злочинних діянь. Питаннями, які під тим чи іншим змістовим кутом зору осмислювалися в рамках ювенальної віктимології раніше та осмислюються в ній нині, $\epsilon$ питання про глибокі, фундаментальні причини, чинники, наслідки ювенальної віктимності, віктимізачії та заходи з ї̈ попередження. Дослідження історії наукового становлення даної підгалузі загальної віктимології допоможе зрозуміти їі суттєві науково-змістові, науково-методологічні та інші прогалини, визначити ї̈ новітні, подальші наукові цілі. Власне, історія наукового становлення ювенальної віктимологї являє собою явну змістову лакуну, прогалину в рамках даної системи знань, яка має бути заповненою. Історія наукового становлення даної сфери віктимологічного та кримінологічного знання відтворюється в комплексному, загально-иільовому науково-віктимологічному контексті визначенні та дослідженні неповнолітньої/малолітньої жертви кримінального злочину як віктимоактивної, віктимо-провокуючої сторони в межах того чи іншого протиправного діяння. Робиться висновок, що сучасна ювенальна віктимологія становить собою окрему, актуальну, важливу, корисну та досить розвинуту підгалузь загальної віктимологї та кримінології. Загалом, ї̈ науково-історичними витоками є природне, стародавнє та перманентне суспільно-чутливе, суспільно-обережливе, суспільно-охоронне ставлення до соиіальних та, зокрема, кримінально-правових проблем дитинства, малолітства та неповноліття.

Ключові слова: дитина, віктимологія, кримінологія, запобігання, злочин.

Постановка проблеми. Історія наукового становлення є обов'язковим, невід'ємним, актуальним, вкрай важливим та необхідним елементом в рамках комплексного змістовно-інформативного базису будь-якої галузі наукового знання. Дане твердження абсолютно рівною мірою стосується і «класичних», тобто досить розвинутих, і так званих «молодих», тобто відносно нових напрямів наукових досліджень. Це є необхідністю та загальноприйнятою вимогою в рамках як минулих, так і сучасних фундаментальних та прикладних, гуманітарних, природничих та точних наук [1]. На основі виявлення, верифікації, фіксації та всебічного розгляду ключових попередніх етапів історичного розвитку певної науки вирішується комплекс важливих суто пізнавальних та інших завдань.

Так, зазираючи у минуле, дослідник визначає та фіксує, по-перше, конкретні основні та додаткові причини, які стали 
поштовхом для розвитку певної системи/ галузі наукового знання в цілому. Ці причини можуть бути причинами соціальнооб'єктивного, природно-об'єктивного та іншого характеру. Однак у їх історичнопричинній основі завжди знаходиться той чи інший елемент або сукупність елементів навколишньої об'єктивної дійсності, часто досить гострого проблематичного характеру. По-друге ж, дослідник виявляє історичні етапи спочатку наївного, інтуїтивного, безсистемного сприйняття, а потім вже і суто зрілого, грунтовного наукового осмислення тієі чи іншої проблематичної дійсності. Таким чином, дослідник відтворює історію формулювання та перегляду, власне, і безпосереднього формування об'єкта та предмета, цілей та завдань, напрямів, функцій та принципів тієї чи іншої системи/галузі наукового знання. По-третє, виявлення, верифікація, фіксація та всебічний розгляд дослідником історії наукового становлення забезпечує оцінку та аналіз ним попередніх помилок, недоліків у межах даної системи/галузі наукового знання. За допомогою зазначених дій формулюються, у свою чергу, загальна стратегічна та тактична перспектива подальшого наукового розвитку, подальшого цілісного опанування тієї чи іншої актуальної наукової проблематики.

Аналіз останніх досліджень і публікацій. Проблеми розвитку віктимологічного вчення розроблено у працях В.В. Голіни, Б.В. Головкіна, А.О. Джужи, О.М. Джужи, В.О. Тулякова, В.І. Шакуна та інших учених. Однак становлення ювенальної віктимологі як окремого кримінологічного вчення ще не досліджувалось.

Метою запропонованої статті $€$ визначення характерних рис становлення ювенальної віктимології як окремого кримінологічного вчення.

Виклад основного матеріалу. Ювенальна віктимологія становить досить актуальну, соціально важливу сферу науково-кримінологічного знання та дослідження. Дана система/галузь науково-кримінологічного знання зумовлюється власним, очевидним надзвичайно гострим соціальним та суто кримінологічним причинно-предметним контекстом - вчиненням кримінальних злочинів проти неповнолітніх та/або малолітніх осіб, причинами та наслідками вчинення проти них тих чи інших злочинних діянь. Питаннями, які в тому чи іншому аспекті осмислювалися в рамках ювенальної віктимології раніше та осмислюються в ній нині, є питання про глибокі, фундаментальні причини, чинники, наслідки ювенальної віктимності, віктимізації та заходи із ії попередження. Дослідження історії наукового становлення даної підгалузі загальної віктимології допоможе зрозуміти її суттєві науково-змістові, науково-методологічні та інші прогалини, визначити іï̈ новітні, подальші наукові цілі. Власне, історія наукового становлення ювенальної віктимології являє собою явну змістову лакуну, прогалину в рамках даної системи знань, яка має бути заповненою.

Отже, загальноісторична природність зародження ювенальної віктимології зумовлена не чим іншим, як саме давнім, значним, гостро-позитивним, ціннісно-етичним, моральним, тобто аксіологічним суспільним ставленням до всього комплексу соціальних, кримінально-правових та інших проблем дитинства, неповноліття, малолітства тощо.

У Євангелії від Матвія сказано: «Хто ж спокусить одне з цих малих, що вірують в Мене, то краще б такому було, коли б жорно млинове на шию йому почепити, і його потопити в морській глибині» [2]. Велике кримінально-правове, антивіктимологічне значення мають і окремі положення іудейсько-християнських Десятьох заповідей (Книга Вихід): не вбивай, не кради, не чини перелюбу, не жадай дому ближнього свого, не жадай дружини ближнього свого, ані раба його, ані невільниці його, ані вола його, ані осла його, ані всього, що ближнього твого [3].

Саме тому В.А. Лелеков та Є.В. Кошелєва прямо зазначають (подається в авторському перекладі з мови-оригіналу джерела): «У Священному Писанні містяться зачатки ювенальної кримінології (i, таким чином, на нашу думку, безумовно, ювенальної віктимології. - прим. авт.). У Біблії містяться поради батькам, суспільству із виховання (зокрема, i антикримінального, і антивіктимного. - прим. aвт.) дітей, засуджується безкарність» [4].

У Сурі ж 17:31 Корану сказано (подається в авторському перекладі з мови-оригіналу джерела): «Не вбивайте дітей своїх, побоюючись злиднів, бо Ми забезпечуємо їхнє і ваше харчування. Воістину, вбивати дітей - тяжкий гріх» [5].

Якщо, у свою чергу, звернутися не до релігійних, а до стародавніх світсько-етичних основ ювенальної кримінології та віктимології, то слід згадати античних грецьких та римських мислителів. У ювенологічних вченнях Стародавньої Греції превалювали ідеї раннього антивіктимного та антикримінального виховання та захисту дітей і молоді в інтересах полісно-державних, полісно-республіканських інститутів. Так, безумовними та вкрай необхідними прямими і опосередкованими виховними засобами попередження дитячої та юнацької криміналізації та віктимізації 
давньогрецькі мислителі-філософи Протагор, Сократ, Платон та Аристотель вважали: суворий підбір для підростаючого покоління художніх творів, роздільне виховання юнаків та дівчат, призначення громадських вчителів за рахунок держави, високоморальне виховання молодих громадян, регулювання шлюбів та народжень, боротьбу із пияцтвом та лихослів'ям, організацію дитячого і молодіжного корисного дозвілля тощо [4, с. 27-28].

Відомі ж давньоримські філософи, історики Цицерон, Тацит, Квінтиліан, Плутарх та інші небезпідставно вважали, що явними, очевидними причинами ювенальної віктимізації та криміналізації є: юридична і фактична безкарність злочинців та їхне власне розвинуте почуття безкарності, загальне недодержання громадянами законів, античні, зокрема римські елітно-патриціанські, системи виховання дітей та молоді (вони, мовляв, розбещують юнацтво, розвивають у ньому культ багатства, розкоші, нестримного гедонізму, а не скромності, працьовитості та добродійства), негативний, зокрема кримінальний, поведінковий приклад власних батьків та багатьох інших дорослих осіб (пияцтво, перелюбство, непристойність, лихослів'я, бійки, войовничість тощо), тілесні покарання (вони надзвичайно озлоблюють, криміналізують і віктимізують малолітніх осіб, дітей) [4, с. 27-28].

Усе сказане безпосередньо стосується також і відповідних думок, поглядів величезної кількості мислителів Середньовіччя, Нового та Новітнього часів. Так, наприклад, Франсуа Раблє, Мішель Монтень, Еразм Роттердамський, Томас Мор, Мартін Лютер, Шарль Монтеск'є, Чезаре Беккаріа, Ян Амос Коменський, Джон Локк, Франсуа Фенелон, Жан-Жак Руссо, Іоганн Песталоцци у своїх філософських, загально-правових, кримінально-правових та інших працях висловлювали думки про те, що попередження злочинів є важливішим, ніж покарання за його вчинення [4, с. 27-28]. У цьому погляді, безумовно, відтворюється безпосередня ювенально-віктимологічна проблематика, яка наголошує на необхідності не лише попередження кримінальних дій стосовно неповнолітніх осіб з боку потенційних злочинців, але й антивіктимно-профілактичної роботи серед дітей, юнацтва, підлітків.

Саме ж попереднє формування загальної та власне ювенальної віктимології пов'язано, у свою чергу, зі становленням та розвитком кримінологічного знання як такого та його предметно-проблематичного, змістовно-проблематичного наукового поля.

Так, у межах антропологічної, соціологічної та біосоціологічної наукових шкіл у кримінології (Ч. Ламброзо, А. Кетле та Ф. фон Ліст відповідно) відтворюється, актуалізується, розглядається та вирішується питання про причини вчинення кримінальних злочинів [4, с. 27-28]. Однак даний суто кримінологічний акцент зосереджується на проблематиці формування особистості та кримінальних нахилів виключно потенційного та/або фактичного злочинця, комплексі причин, витоків його протиправної поведінки тощо. Даний суб'єктно-центричний підхід до проблематики причин вчинення кримінальних злочинів не передбачав урахування чинника жертви/потерпілої особи в рамках протиправного діяння в якості, як це не дивно, активної, віктимно-провокуючої, віктимно-активної, «віктимно-винуватої» сторони.

Віктимологічна «революція» у світовій, зокрема європейській, кримінології пов'язана з ім'ям та вагомим науково-кримінологічним внеском німецького науковця-правника Г. Гентінга. У своїх працях «Зауваження по інтеракції між злочинцем і жертвою» та «Злочинець і його жертва. Дослідження із соціобіології злочинності» він зазначав, що «жертву слід розглядати як один із причинних факторів злочину», що «жертва злочину не повинна розглядатися як пасивний об'єкт, тому що вона - активний суб'єкт процесу криміналізації (i, таким чином, власної віктимізації. - прим. авт.)» [6, с. 118]. Так, сам Г. Гентінг надзвичайно чітко зазначав із цього приводу таке: «Якщо ми вважаємо, що є природжені злочинці, то є і природжені жертви» [7]. Така позиція відтворює суто антропологічний підхід тепер у рамках віктимологічного знання.

Загалом, поведінка людини за своєю природою може бути не лише злочинною, але й віктимною, тобто небезпечною для неї самої, необережною, ризикованою та, таким чином, за певної ситуації може стати приводом для вчинення (проти неї, людини. - прим. авт.) злочинного діяння [8, с. 417].

Таким чином, віктимологія як така $\epsilon$ досить новим, «молодим» підгалузевим напрямом у рамках системи кримінологічного знання. Так, наприклад, А.І. Савельєв зазначає з цього приводу (подається в авторському перекладі з мови-оригіналу джерела): «Натепер, коли науковий прогрес (науковокримінологічний прогрес. - прим. авт.) багато в чому є наслідком диференціації та інтеграції окремих галузей наукового пізнання, 3 урахуванням значущості проблеми охорони громадян, яким найбільшою мірою загрожує віктимізація, постає питання про необхідність всебічного вивчення жертв злочинів. Цю роль взяв на себе порівняно новий напрям кримінологї - віктимологія (курсив мій. - авт.), 
і низка вчених дотримуються думки про необхідність виокремлення в її рамках ювенальної віктимології» [9, с. 61].

А.О. Борисова, зі свого боку, також зазначає щодо історії розвитку загального віктимологічного знання (подається в авторському перекладі 3 мови-оригіналу джерела): «Протягом тривалого часу правоохоронні органи однобічно орієнтувалися на роботу навколо злочину та злочинця без належної уваги до жертви злочину. Як наслідок, від нагоди до нагоди проводяться заходи віктимологічної профілактики, і в цілому потерпіла особа нерідко розглядається лише як джерело інформації про злочинця та злочин, як учасник (сторона) кримінально-процесуальних відносин. Між тим майже усе світове співтовариство починаючи із кінця 1940-х років послідовно впроваджує ідею захисту жертв злочинів від свавілля злочинців та властей. У цьому напрямі вдосконалюється національне законодавство, проводяться семінари, симпозіуми, створюються різного роду соціальні служби, фонди допомоги, дома довіри та порятунку потерпілих. Поряд із професійною діяльністю за фактом злочину не менш професійно проводиться робота із жертвами злочинів в інтересах недопущення їхньої повторної віктимізації» [10, с. 119].

Однак першим науковцем-правником, науковцем-кримінологом, який запровадив у науковий обіг термін/поняття «віктимологія», був румунський дослідник Б. Мендельсон. Так, у 1975 році у монографії «Загальна віктимологія» він запропонував віктимологічну концепцію «клінічної» або «практичної» віктимології, до змісту поняття якої мали бути включені не лише жертви злочинів, але й жертви природних катаклізмів, геноциду, етнічних конфліктів, війн [6, с. 119].

Загалом, П.В. Сорокун виділяе чотири етапи розвитку суто віктимологічного знання: 1) перша половина XIX ст., коли ця проблематика була вперше актуалізованою А. Фейєрбахом («Документальний виклад знаменитих злочинів») та Ф.Т. Джасом («Вбивство та мотиви»); 2) середина ХХ ст., коли з'явилася перша віктимологічна стаття вже згаданого Г. Гентінга «Злочинець та його жертва»; 3) друга половина XX ст., коли вийшли у світ науково-віктимологічні праці Б. Мендельсона («Походження та доктрина віктимології, «Загальна віктимологія») та праці Ф. Вертхама, А. Фаттаха, Х. Нагеля та Р. Гассера; 4) 70-80-ті роки ХХ ст., коли було засновано Всесвітне товариство віктимологів [11, с. 111].

Що ж стосується відокремлення нині власне ювенальної віктимології від загальної, то, наприклад, британський дослідник наво- дить таку науково-історичну довідку з цього питання (подається в авторському перекладі з мови-оригіналу джерела): «У більшості британських наукових досліджень 3 проблематики «молодь та кримінальні злочини» увага фокусується на молодих людях в якості правопорушників, а не жертв кримінальних злочинів. Однією із перших спроб зосередитися на проблематиці ювенальної віктимізації (курсив мій. - авт.) слід вважати дослідження Моубі (1979р.), яке проводилося щодо учнів від 11 до 15 років із двох шкіл Шеффілду. Він виявив, що 40 відсотків стали жертвами крадіжок, а 25 відсотків були жертвами фізичного нападу. Загалом 67 відсотків повідомили, що вони були жертвами злочинів» [12, с. 20]. Суттєвою етапно-змістовою «революцією» саме у західній ювенальній віктимології стали запровадження та розвиток декількох авторитетних теоретичних моделей, науковим призначенням яких є пояснення поступового, а також «не» механізму дитячої, малолітньої та неповнолітньої віктимізації.

Так, К.В. Вишневецький зазначає, що найбільш поширеною західною моделлю $€$ циклічна модель, згідно з якою насильство, протиправні діяння по відношенню до дітей здійснюють переважно особи, які самі у дитинстві стали жертвами подібного насильства. Представником цієї моделі є відомий американський кримінолог-віктимолог К. Дадж. Він дослідив цикл розвитку агресивних тенденцій у дитини, проаналізувавши соціальні умови розвитку 309 чотирьохлітніх дітей у дитячих садочках штатів Тенісі та Індіана. К. Дадж взяв інтерв'ю у матерів, персоналу, вивчив також необхідні психологічні параметри у дітей. Він використовував метод прямого спостереження. Було виявлено, що діти, які зазнавали фізичного насильства в сім'ї, були більш агресивними по відношенню до інших дітей: «індекс агресії» у скривдженої дитини був на 93 \% вищий, ніж у інших дітей. К. Дадж дійшов висновку про те, що дитина, яка раніше стала жертвою насильства в сім'ї, була найменш здатною обробити інформацію та вирішити проблеми міжособистісного спілкування у толерантній формі. К. Дадж вважає, що модель агресивної поведінки, яка відтворюється у ранньому дитинстві, може здійснити екстраполюючий вплив на майбутні дії агресії в тому числі й у формі злочинів проти суспільства. Віктимізація дитини, таким чином, детермінує криміналізацію дорослої особи [13, с. 266-267].

Іншою моделлю, яка свого часу увійшла у науковий ювенально-віктимологічний обіг, є психопатологічна модель. На нашу думку, вона достатньою мірою відповідає, скажімо так, науково-цільовому призначенню як 
загальної, так і ювенальної віктимології розкриттю та обгрунтуванню віктимо-провокуючої, віктимо-активної поведінки потенційної неповнолітньої жертви кримінальних злочинів. Так, у цій моделі акцент робиться на необхідних, важливих характеристиках та ролі самого молодого «віктима». Ця модель включає в себе три особливих підходи до проблеми жорсткого поводження із дітьми, які характеризуються як психодинамічна модель, модель психічного захворювання та модель рис характеру [13, с. 267]. Не менш актуальною є і так звана кримінологічноінтеракціоністська модель. Ї̈̈ засновники (Х. Мартін) виділяють три основні чинники жорстокого поводження із дітьми, потенційними майбутніми неповнолітніми, малолітніми віктимами. Цими чинниками є: роль дитини, випадкові події, структура дисфункціональної родини [13, с. 267].

Однією із науково перспективних західних віктимологічних моделей є соціологокультурологічна модель Н. Полянські. Ця модель розглядає жорстоке поводження із дітьми як результат суспільних напружень, які є первинними причинами зловживань. До цієї моделі можуть бути віднесені такі приватні соціо-віктимологічні моделі, як, наприклад, модель соціального напруження, соціально-психологічна модель та психосоціологічна модель [13, с. 267].

Є.Д. Якімова слушно зазначає (подається в авторському перекладі з мови-оригіналу джерела): «Можна виділити деякі країни, де віктимологія (зокрема, і ювенальна. - прим. aвт.) розвивається найбільш інтенсивно (США, Німеччина, Канада, Швейцарія, Японія, Італія,) і де відбувається активна розробка практичних аспектів віктимологічного напряму профілактики правопорушень. Так, наукові центри у деяких університетах США організовують спеціальні віктимологічні клініки. У навчальних закладах поліції Німеччини викладається спеціальний курс із основ віктимології, читаються лекції із застосування положень цього курсу в поліцейській практиці. В Японії застосовуються спеціальні лабораторії психології, виховної праці, які досліджують особистість та поведінку потерпілих осіб, шкоду, яку їм було завдано, форми взаємин між жертвою та правопорушниками» [14, с. 56].

\section{Висновки}

Сучасна ювенальна віктимологія становить собою окрему, актуальну, важливу, корисну та досить розвинуту підгалузь загальної віктимології та кримінології. Її науково-історичними витоками є природне, стародавне та перманентне суспільно-чутливе, суспільно-обережливе, суспільно-охоронне ставлення до соціальних та, зокрема, кримінально-правових проблем дитинства, малолітства та неповноліття. Історія наукового становлення даної сфери віктимологічного та кримінологічного знання відтворюється в комплексному, загально-цільовому наукововіктимологічному контексті - визначенні та дослідженні неповнолітньої/малолітньої жертви кримінального злочину як віктимоактивної, віктимо-провокуючої сторони в рамках того чи іншого протиправного діяння.

\section{Список використаних джерел:}

1. Назимко Є. С. Історичний метод та проблеми періодизації історії розвитку інституту покарання неповнолітніх. Jurnalul Juridic National: teorie si. 2014. № 1. C. 47-57.

2. Біблія. Новий Заповіт. Книга Вихід, 20: 13 14, 15, 17. URL: http://www.my-bible.info/biblio/ ukrainskaya-bibliya/ishod.html. Євангеліє від Матвія, 18:6. URL: https://www.bibleonline.ru/bible/ $\mathrm{ukr} / 40 / 18 / \# 6$

3. Біблія. Старий Заповіт. Книга Вихід, 20: 13, 14, 15, 17. URL: http://www.my-bible.info/biblio/ ukrainskaya-bibliya/ishod.html.

4. Лелеков В.А., Кошелева Е.В. Ювенальная криминология : учебник. Воронеж: ВИ МВД России, 2012.495 с

5. Коран. URL: http://timesofu.com/books/1/ quran.pdf

6. Давиденко В. Л. Віктимологія як галузь кримінологічної науки. Європейські перспективи. 2014. № 8. C. 118-121.

7. Hentig G. Remarks on the Interaction of Perpetrator and Victim. The Journal of Criminal Law and Criminology. 1941. V. 31. P. 304.

8. Вишневецкий К.В. Классификация виктимности. Теория и практика общественного развития. 2014. № 2. С. 417-418.

9. Савельев А.И. Несовершеннолетние жертвы преступлений как объект виктимологического исследования. Психопедагогика в правоохранительных органах. 2012. № 1 (48). С. 61-65.

10. Борисова А.А. Виктимологические аспекты профилактики преступлений в отношении несовершеннолетних. Вестник Международного института экономики и права. 2015. № 4 (21). C. $75-80$.

11. Сорокун П.В., Лексина Д. О. История развития виктимологии. ЭПИ Международный научно-практический журнал «эпоха науки». 2017. № 12. C. 110-112.

12. John Muncie. Youth Victimization. Cjm. Autumn, 2000. № 41.

13. Вишневецкий К.В. Виктимность несовершеннолетних и проблемы социализации личности. Теория и практика общественного развития. 2012. № 9. С. 265-270.

14. Якимова Е.Д. Виктимологическая профилактика преступности: содержание и задачи. Виктимология. 2014. № 1 (1). С. 55-58. 
The article reveals the features of the formation of juvenile victimology as a separate criminological doctrine. The historical origins and development of juvenile victimology are analyzed. It is noted that the general historical naturalness of the birth of juvenile victimology is due to nothing other than the ancient, significant, acutely positive value-ethical, moral, that is, axiological public attitude to the whole complex of social, criminal-legal and other problems of childhood, minority, childhood, etc. $d$. It is argued that juvenile victimology is a fairly relevant socially important area of scientific and criminological knowledge and research. This system / branch of scientific and criminological knowledge is determined by its own, extremely sharp social and purely criminological causal subject-specific context - the commission of criminal offenses against minors and / or minors, the causes and consequences of the commission of certain criminal acts against them. Questions that have been interpreted within the framework of juvenile victimology from one or another substantive point of view, and are still interpreted in it so far, are questions about the deep, fundamental causes, factors, consequences of juvenile victimization, victimization and measures to prevent it. The study of the history of the scientific development of this sub-sector of general victimology will help to understand its essential scientific, scientific, methodological and other gaps, to define its newest, further scientific goals. The actual history of the scientific development of juvenile victimology is a clear, informative lacuna, a gap in the framework of this knowledge system, which must be filled. The history of the scientific development of this sphere of victimological and criminological knowledge is reproduced in a complex, targeted scientific victimological context - the definition and study of a minor / minor victim of a criminal offense as a victim-active, victim-provoking party in the framework of a wrongful act. It is concluded that modern juvenile victimology is a separate, relevant, important, useful and sufficiently developed sub-branch of general victimology and criminology. In general, its scientific and historical origins are a natural, ancient and permanent socially sensitive, socially-accustomed, socially protective attitude to the social and, in particular, criminal law problems of childhood, childhood and minority.

Key words: child, victimology, criminology, prevention, crime. 